\title{
PEMBERDAYAAN FORUM ANAK SURAKARTA SEBAGAI PEER EDUCATOR UNTUK MENGATASI TINDAK KEKERASAN TERHADAP ANAK
}

\author{
Sri Yuliani ${ }^{1}$, Rahesli Humsona ${ }^{2}$, Sigit Pranawa ${ }^{3}$
}

\begin{abstract}
Abstrak
Kasus kekerasan terhadap perempuan dan anak di Kota Surakarta masih cukup tinggi, baik jumlah maupun kualitas kekerasannya. Meskipun di Kota Surakarta telah dibentuk lembaga Pelayanan Terpadu Perempuan dan Anak Surakarta (PTPAS), upaya menangani kasus-kasus kekerasan terhadap perempuan dan anak belum dapat dilakukan secara optimal. Banyaknya lembaga yang bergabung dengan PTPAS belum memberi jaminan perlindungan bagi korban kekerasan. Salah satu kendala upaya penanganan korban kekerasan terhadap anak adalah belum terbangunnya perspektif terhadap korban yang lebih baik. Anak korban kekerasan mengalami hambatan psikologis dan komunikasi untuk menyampaikan masalahnya baik dengan keluarga maupun pendamping korban dari LSM atau PTPAS. Forum Anak Surakarta (FAS) sebagai lembaga partisipasi anak dalam pembangunan selama ini telah menjadi media berbagi permasalahan dengan teman sebaya, termasuk masalah tindak kekerasan terhadap anak. Pemberdayaan Forum Anak Surakarta sebagai Peer Educator (pendidik sebaya) menjadi solusi efektif untuk memecahkan hambatan komunikasi dalam pendampingan anak korban kekerasan. Untuk itu pengabdian ini bertujuan memberikan skill pada FAS agar mampu berperan sebagai counselor bagi teman sebaya yang mengalami tindak kekerasan.Khalayak sasaran adalah 15 anak (usia 13-18 tahun) yang tergabung dalam Forum Anak Surakarta. Adapun kegiatan pengabdian meliputi : 1) Penyadaran tentang kekerasan anak dan hak perlindungan anak; 2) pelatihan sebagai advokator agar aspirasi anak korban kekerasan diakomodir dalam Musyawarah Perencanaan Pembangunan, dan 3) praktek atau simulasi konselor sebaya bagi anak korban kekerasan. Setelah mengikuti pelatihan dan praktek pendidikan sebaya, anak-anak yang tergabung dalam Forum Anak Surakarta menjadi : 1) semakin meningkat kesadarannya tentang dampak kekerasan anak dan pentingnya hak perlindungan anak dan 2) memahami mekanisme sebagai advokator dan mampu mempraktekkan tehnik Peer Educator bagi anak korban kekerasan.
\end{abstract}

Keywords : Pemberdayaan, Forum Anak, Peer Educator, Tindak Kekerasan Terhadap Anak.

\footnotetext{
${ }^{1}$ Program Studi IImu Administrasi Negara Fakultas IImu Sosial dan Politik, UNS, (sriyuliani63@staff.uns.ac.id)

2 Program Studi Sosiologi Fakultas IImu Sosial dan Politik UNS

3 3Program Studi Pendidikan Sosiologi Antropologi FKIP UNS
} 


\section{PENDAHULUAN}

Kota Surakarta atau disebut juga Kota Solo merupakan daerah dengan kasus kekerasan terhadap perempuan dan anak tergolong tinggi di Tingkat Jawa Tengah. Dari 7 (tujuh) Kabupaten/Kota di Wilayah se Karesidenan Surakarta, Kota Surakarta memiliki angka kekerasan terhadap perempuan dan anak yang paling tinggi. Pada tahun 2003 terdapat 400 lebih korban kekerasan berbasis gender, tahun 2009 ada 24 anak korban kekerasan secara seksual, fisik maupun psikis dan tahun 2010 terdapat 5 anak. Anak yang menjadi korban eksploitasi seks komersial anak (ESKA) berdasarkan penjangkauan dan pendampingan Yayasan KAKAK di Surakarta sebanyak 29 anak pada tahun 2009 dan 13 anak di tahun 2010 (Bapermas P3A-KB dalam Baseline Data KLA, Unicef dan Bapeda Kota Surakarta). Yayasan Kakak mendata jumlah anak yang menjadi korban kekerasan seksual di Surakarta bertambah setiap tahunnya. Terdapat sekitar 31 anak korban kekerasan anak yang didampingi oleh Yayasan Kakak pada tahun 2014. Sebagian besar korban berusia antara 7 sampai 12 tahun. Sisanya, korban berusia di bawah 6 tahun sebanyak 5 anak, 13-15 tahun terdapat 7 anak dan 16-18 tahun berjumlah 7 anak. Pada tahun 2015, jumlah korban bertambah menjadi 33 orang dengan korban didominasi oleh anak-anak berusia
13-15 tahun sebanyak 18 orang. Korban berusia 5- 6 tahun meningkat menjadi 6 anak. Tahun 2016 korban kekerasan seksual paling banyak dari kalangan remaja dengan jumlah sekitar 14 orang. Sementara anak yang berusia 5-12 tahun berjumlah 12 orang (Solotrust.com, 2017).

Laporan kasus kekerasan seks yang dialami anak-anak di Kota Solo menjadi paling tinggi diantara deretan kasus-kasus terhadap anak-anak. Dinas Sosial Kota Solo mencatat laporan kasus kekerasan seks yang dialami anak pada 2017 mencapai 17 kasus. Psikolog Dinas Sosial Kota Solo, Wiwik Widiyanti menyatakan dari 77 laporan kasus terkait anak sebanyak 17 laporan merupakan kasus kekerasan seks pada anak, 8 kasus terkait laporan anak terlantar, dan 9 kasus penganiayaan pada anak. Kendati demikian terdapat sekitar 138 anak di Kota Solo termasuk ke dalam resiko tinggi menghadapi masalah-masalah anak. Jumlah tersebut berasal dari keluarga kategori rumah tangga sangat miskin yang terdapat di lima Kelurahan di Kota Solo diantaranya Mojosongo, Jebres, Kadipiro, Nusukan, dan Semanggi (Republika, Jan 2018)

Komisi Perlindungan Anak Indonesia (KPAI) menemukan ratusan kasus kekerasan seksual terhadap anak diduga dilakukan orang terdekat sebagai pelaku. Komisioner KPAI Jasra Putra 
mengungkapkan "Dalam data kami menyatakan pelakunya adalah orang terdekat anak seperti ayah tiri dan kandung, keluarga terdekat, dan temannya," kata Jasra kepada JawaPos (Kuswandi , JawaPos, 2017). Gejala yang sama dikemukakan oleh Ketua Komisi Perlindungan Korban Kekerasan Berbasis Gender dan Anak (KPK2BGA) Jawa Tengah Handinah Katjasungkana. Kekerasan anak di Jawa Tengah pada tahun 2012 ada 483 kasus dengan korban 78 anak laki-laki dan 405 anak perempuan. Pada 2013 ada 595 kasus dengan korban anak laki-laki 104 dan 491 anak perempuan. Di tahun 2014 kasus meningkat menjadi 799 kasus dengan perincian yang menjadi korban 152 lakilaki dan 627 anak perempuan. Data dari berbagai monitoring KPK2GBA, laporan pusat pelayanan terpadu (PPT) perempuan dan anak di 35 kabupaten/kota, serta laporan masyarakat menemukan mayoritas kekerasan terhadap anak adalah kekerasan seksual yang mayoritas korbannya anak perempuan. Pelaku kekerasan seksual anak lebih banyak orang yang dikenal atau orang dekatnya. Bahkan anak juga bisa menjadi pelaku kekerasan seksual. Handinah memperkirakan kasus kekerasan lebih banyak lagi karena banyak kasus yang tidak terungkap (Tempo, 1 Desember 2015).
Melihat situasi ini, Dinas Pemberdayaan Perempuan, Perlindungan Anak dan KB Kota Surakarta melakukan edukasi kepada masyarakat terutama anakanak(http://jateng.tribunnews.com/tag/anakanak), agar berani memberikan laporan jika mengalami dan menemukan tindak kekerasan pada anak di sekitar lingkungannya. Untuk memberikan pendampingan terhadap anak korban kekerasan, Pemkot mempunyai Pelayanan Terpadu Bagi Perempuan dan Anak Kota Solo (PTPAS) yang mendampingi perempuan dan anak$\operatorname{anak(http://jateng.tribunnews.com/tag/anak-~}$ anak) yang mengalami kekerasan serta melakukan assesment, konseling hingga pendampingan psikologis atas masalah yang dihadapi anak. (Jateng tribunnews.com, 23 Oktober 2016).

Masalahnya adalah meskipun telah terbentuk PTPAS angka kekerasan terhadap anak masih relatif tinggi. Upaya perlindungan anak dari tindak kekerasan dan eksploitasi anak jelas tidak bisa dijalankan oleh pemerintah sendiri. Banyak kasus kekerasan terhadap anak yang sulit dideteksi dan diketahui karena berada di ranah privat - di lingkup rumah tangga- sehingga lembaga pemerintah kurang kapasitas untuk menanganinya. Institusi pemerintah jelas tidak akan 
mampu menangani persoalan semacam ini tanpa partisipasi masyarakat.

Salah satu kendala upaya penanganan korban kekerasan terhadap anak adalah belum terbangunnya perspektif terhadap korban yang lebih baik. Anak korban kekerasan mengalami hambatan psikologis dan komunikasi untuk menyampaikan masalahnya baik dengan keluarga maupun pendamping korban dari LSM atau PTPAS. Forum Anak Surakarta (FAS) sebagai lembaga partisipasi anak dalam pembangunan selama ini telah menjadi media berbagi permasalahan dengan teman sebaya, termasuk masalah tindak kekerasan terhadap anak (FGD dengan FAS, 5 Agustus 2017). Pemberdayaan Forum Anak Surakarta sebagai Peer Educator (pendidik sebaya) menjadi solusi efektif untuk memecahkan hambatan komunikasi dalam pendampingan anak korban kekerasan. Peran Forum Anak di dalam pencegahan dan identifikasi anak korban kekerasan sangatlah penting karena dengan adanya kesadaran anak yang tinggi, maka anak dapat mencegah dirinya sendiri dan anak di sekitarnya menjadi korban perdagangan anak. Dalam rangka membantu Forum Anak Surakarta agar mampu berperan sebagai pendidik sebaya, maka pengabdian masyarakat ini bertujuan memberikan penyadaran tentang kekerasan terhadap anak, dampak dan pencegahannya serta memberikan pelatihan konselor sebaya untuk mengatasi tindak kekerasan pada anak

\section{METODE PELAKSANAAN}

Mekanisme pelaksanaan kegiatan pengabdian ini terdiri empat tahapan yaitu : a) Perencanaan ; b) Tindakan ; c) Observasi dan Evaluasi; dan d) Refleksi. Dalam Tahap Perencanaan, tim pelaksana kegiatan mempersiapkan perijinan, mekanisme dan metode pelaksanaan kegiatan penyuluhan kepada semua pihak yang akan dilibatkan. Sosialisasi kegiatan ke kelompok mitra yang terdiri dari Forum Anak Surakarta dan Yayasan Kakak selaku LSM yang bergerak di perlindungan hakhak anak, serta melakukan pre-test untuk megidentifikasi kebutuhan dan permasalahan dengan kelompok sasaran. Tahap Tindakan merupakan pelaksanaan kegiatan penguatan kapasitas yang meliputi kegiatan penyadaran dan pelatihan atau simulasi sebagai konselor sebaya. Kegiatan penyadaran dimaksudkan untuk menumbuhkan pemahaman anak tentang hak anak untuk mendapat perlindungan dari tindak kekerasan. Pelatihan konselor sebaya diberikan dalam bentuk praktek atau simulasi pendampingan anak korban kekerasan yang dilakukan dengan metode diskusi kasus dan peran teater. Selanjutnya dilakukan observasi dan evaluasi terhadap 
proses pelatihan yang dilaksanakan untuk mengetahui sejauhmana pemahaman peserta terhadap materi dan perubahan sikap yang terjadi. Tahap terakhr dilakukan kegiatan refleksi terhadap kegiatan yang telah dilaksanakan.untuk mengetahui : a) kendala-kendala, kekurangan dan kelemahan yang muncul selama proses pelaksanaan kegiatan pelatihan; b) kualitas materi dan metode pelatihan; dan c) keberlanjutan kegiatan atau program pengabdian.

\section{HASIL DAN PEMBAHASAN}

\subsection{Profil Forum Anak Surakarta}

Forum Anak Surakarta (FAS) adalah forum anak di tingkat kota yang berfungsi sebagai forum komunikasi yang dikelola oleh anak-anak dan dibina oleh pemerintah yang digunakan sebagai wadah partisipasi anak dimana anggotanya adalah anak secara individu atau dari perwakilan kelompok anak, sebagai media untuk mendengar dan memenuhi aspirasi suara, pendapat, keinginan, dan kebutuhan anak dalam proses pembangunan.

Selain sebagai wadah partisipasi anak dalam pembangunan, Forum Anak Surakarta juga berfungsi : 1) Sebagai media pantauan pelaksanaan pemenuhan hak anak, 2) Sebagai media sosialisasi program kegiatan terkait dengan hak anak di lingkungan teman sebaya, 3) Sebagai media menyuarakan aspirasi anak, 4) Mendorong keterlibatan anak dalam proses pengambilan keputusan, dan 5) Mendorong anak-anak aktif mengembangkan potensinya.

Forum Anak Surakarta dibentuk sekitar tahun 2008. FAS menjadi media bagi anak-anak di Surakarta untuk berpartisipasi, menampung aspirasi, serta memperjuangkan hak-hak anak dan sekaligus menjadi forum komunikasi antar anak di Kota Surakarta. FAS dilandasi oleh prinsip-prinsip : a) non-diskriminasi atau universalitas, b) kepentingan terbaik bagi anak, c) penghargaan bagi anak, dan d) terbuka dan tidak mengikat.

Keanggotaan FAS terdiri dari : a) Anggota biasa, yaitu anggota yang berumur 14 sampai 18 tahun yang berdomisili dan beraktivitas di Surakarta; b) Anggota khusus, yaitu alumni FAS (anggota biasa yang telah berumur lebih dari 18 tahun) yang masih dibutuhkan bantuan tenaga dan pikirannya oleh FAS; dan c) Anggota kehormatan, yaitu anggota yang diangkat oleh pengurus FAS atas jasanya terhadap FAS.

Kepengurusan FAS berlangsung selama periode waktu 3 (tiga) tahun. Tata cara pemilihan ketua dengan dipilih oleh anggota. Keanggotaan bersifat terbuka dan menjangkau seluruh wilayah. Adapun kegiatan FAS murni direncanakan oleh 
anak dengan didampingi oleh orang dewasa. Kepengurusan dan kegiatan FAS pada dasarnya sama dengan forum anak lainnya. Kelebihan FAS dibanding forum anak lainnya adalah apabila forum anak lainnya belum terlibat cukup aktif dalam Musyawarah Perencanaan Pembangunan (Musrenbang) maka FAS merupakan forum anak di level kota yang dilibatkan cukup aktif dalam Musrenbang. Aspirasi anak disampaikan FAS dengan beragam cara, ada sebagian yang disampaikan sendiri secara langsung, ada yang disampaikan lewat fasilitator dan ada yang secara tertulis.

\subsection{Forum Anak Surakarta sebagai Peer}

Educator Untuk Mengatasi Kekerasan

\section{Terhadap Anak}

Kekerasan terhadap Anak adalah segala perbuatan terhadap anak yang berakibat timbulnya kesengsaraan atau penderitaan secara fisik, psikis, seksual, dan atau penelantaran, termasuk ancaman untuk melakukan perbuatan, pemaksaan termasuk eksploitasi ekonomi, atau perampasan kemerdekaan secara melawan hukum (Kementerian Pemberdayaan Perempuan dan Perlindungan Anak, 2016)

Peer Educator adalah anak yang mempunyai pengaruh positif terhadap teman-temannya untuk menimbulkan kepercayaan dan menghindari kecurigaan teman-temannya. Strategi Peer Education punya peran yang strategis didalam mengatasi tindak kekerasan terhadap anak mengingat korban kekerasan terlebih kekerasan seksual pelakunya justru kebanyakan dari orang terdekat anak atau keluarga sehingga anak cenderung menyimpan rapat-rapat kasus kekerasan yang dialami untuk diri sendiri dan enggan melaporkan pada orang luar atau orang dewasa. Teman sebaya dipandang paham betul dengan psikologi sebaya sehingga lebih dipercaya sebagai tempat berbagi pengalaman.

Pendidikan sebaya merupakan bentuk implementasi Hak Anak untuk berpartisipasi dalam upaya pencegahan tindak kekerasan terhadap anak dan untuk menyebarkan pengetahuan dengan harapan anak-anak yang menjadi peserta kegiatan pendidikan sebaya dapat berbuat banyak menyampaikan ilmu yang mereka dapatkan kepada teman sebaya (indo.act, 2014).

Manfaat Peer Education (Pana dan lesta, no date) antara lain : 1) Memberikan lingkungan yang nyaman bagi anak muda untuk berbagi persoalan seputar tindak kekerasan yang dialami, 2) Meningkatkan pengetahuan dan pemahaman anak muda akan tindak kekerasan dan akar penyebabnya, 3) Membantu anak muda untuk menyadari hak dan tanggungjawabnya terkait relasi kuasa dengan teman sebaya, 4) Memberdayakan 
anak muda dengan ketrampilan dan rasa percaya diri sebagai agen perubahan di komunitasnya, 5) Menyediakan media pendidikan untuk mencegah tindak kekerasan bersama-sama dengan teman sebaya, dan 6) Meningkatkan relasi sebaya yang berbasis saling menghargai, toleransi dan kesetaraan

Pendidikan untuk sebaya sangat penting untuk memberi pemahaman tentang bahaya kekerasan kepada anak. Dengan pendidikan sebaya, anak-anak dapat berpartisipasi untuk melakukan pencegahan dan mampu melakukan identifikasi anak yang menjadi korban perdagangan anak dan eksploitasi.

Untuk mencegah aksi kekerasan pada anak, Dinas Pemberdayaan Perempuan, Perlindungan Anak, dan Pemberdayaan Masyarakat (Dinas PP PA dan PM) Kota Surakarta pada tahun 2016 mencanangkan Program Pendidik Sebaya dari anak berusia 12 hingga 18 tahun. Pendidik sebaya sifatnya pencegahan, karena sangat sulit menjangkau 164 ribu anak di Surakarta. Pendidik anak saat ini berjumlah 70 orang dan direncanakan memberi pelatihan untuk 51 kelurahan di Kota Solo. Pendidik sebaya ini diharapkan akan melatih anak lainnya hingga semua anak bisa membentengi dirinya dari ancaman kekerasan. Pendidikan sebaya dipandang efektif untuk mengatasi tindak kekerasan terhadap anak karena biasanya anak dapat lebih banyak bercerita tentang masalah yang dihadapinya dengan teman sebayanya. Pendidik sebaya direkrut dari anggota Forum Anak dan alumni forum anak. (FGD dengan FAS 30 Maret 2018; Isnanto, 2016).

Permasalahannya, puluhan pendidik sebaya di Kota Solo belum sepenuhnya mampu menjalankan tugasnya. Mereka masih membutuhkan pelatihan pendidikan sebaya atau konselor sebaya untuk dapat mendampingi anakanak korban kekerasan (koransolo.co, 2016)

Penelitian Yuliani, Humsona dan Haryanti (2015 - 2016) mengidentifikasi beberapa faktor yang menjadi kendala bagi Forum Anak untuk berperan sebagai pendidik sebaya, antara lain :

1. Belum semua anggota Forum Anak sadar akan hak-hak anak, kekerasan terhadap anak dan dampaknya bagi kehidupan anak

2. Belum ada pelatihan khusus secara intensif yang membekali anggota Forum Anak dengan pengetahuan dan tehnik pendidikan sebaya, khususnya metode konselor sebaya

3. Pembina dan pendamping Forum Anak kurang mampu memahami dunia anak dan remaja dan belum paham tehnik memotivasi dan 
mendampingi anak khususnya agar mampu berperan sebagai pendidik sebaya

Hasil pre-test tentang keterlibatan FAS dalam pendidikan sebaya memperkuat temuan riset Yuliani et al (2017-2018). Gambaran tentang peran FAS sebagai pendidik sebaya nampak dalam tabel berikut :

Tabel 1. Keterlibatan FAS dalam Pendidikan Sebaya

\begin{tabular}{|c|c|c|}
\hline No & $\begin{array}{c}\text { Pertanyaan } \\
\text { Pre-test }\end{array}$ & Jawaban \\
\hline 1 & $\begin{array}{l}\text { Keterlibatan } \\
\text { dalam } \\
\text { Pendidikan } \\
\text { Sebaya }\end{array}$ & $\begin{array}{lr}\text { Hampir } & \text { semua } \\
\text { (13 dari } 15 \text { anak } \\
\text { peserta pelatihan) } \\
\text { pernah terlibat } \\
\text { sebagai pendidik } \\
\text { sebaya }\end{array}$ \\
\hline 2 & $\begin{array}{l}\text { Kapan mulai } \\
\text { mendapatkan } \\
\text { pelatihan } \\
\text { pendidik sebaya }\end{array}$ & $\begin{array}{l}\text { Mulai menjadi } \\
\text { pendidik sebaya } \\
\text { setelah bergabung } \\
\text { dengan FAS (sejak } \\
\text { masuk SMA) }\end{array}$ \\
\hline 3 & $\begin{array}{l}\text { Pelatihan } \\
\text { pendidik sebaya } \\
\text { yang telah } \\
\text { didapatkan }\end{array}$ & $\begin{array}{l}\text { Semua anak } \\
\text { pernah } \\
\text { mendapatkan } \\
\text { pelatihan namun } \\
\text { sangat jarang atau } \\
\text { kurang intens, } \\
\text { khususnya sebagai } \\
\text { konselor sebaya }\end{array}$ \\
\hline 4 & $\begin{array}{l}\text { Pelatihan yang } \\
\text { dibutuhkan } \\
\text { sebagai } \\
\text { pendidik sebaya }\end{array}$ & $\begin{array}{l}\text { Cara menangani } \\
\text { kekerasan anak } \\
\text { khususnya } \\
\text { bullying ( } 1 \text { anak) } \\
\text { Menjadi pendidik } \\
\text { dan konselor } \\
\text { sebaya yang baik } \\
\text { (2 anak) } \\
\text { Menghadapi dan } \\
\text { mengenali } \\
\text { permasalahan } \\
\text { remaja ( } 3 \text { anak) } \\
\text { Meningkatkan }\end{array}$ \\
\hline
\end{tabular}

\begin{tabular}{|l|l|}
\hline & $\begin{array}{l}\text { rasa percaya diri } \\
\text { untuk menjadi } \\
\text { pendidik sebaya (5 } \\
\text { anak) } \\
\text { Tidak Menjawab } \\
\text { (2 anak ) }\end{array}$ \\
\hline
\end{tabular}

Sumber : Diolah dari pertanyaan Pre-Test (Dari 15 kuesioner yang dibagikan yang mengembalikan 13 anak)

Dari hasil pre-test disimpulkan materi yang penting bagi penguatan kapasitas Forum Anak Surakarta adalah: 1) Hak-Hak Anak khusunya Perlindungan Anak dari Kekerasan, 2) Pelatihan untuk menangani bullying dan kekerasan anak dan 3) Menjadi konselor sebaya yang baik bagi teman yang mengalami tindak kekerasan. Berdasarkan identifikasi kebutuhan dari hasil pre-test, maka pengabdian masyarakat ini menawarkan solusi sebagai berikut :

1. Melakukan penyadaran tentang ancaman kekerasan pada anak dan pencegahannya

2. Memberikan pemahaman kepada anakanak yang tergabung dalam Forum AnakKota Surakarta tentang pentingnya pendidikan sebaya untuk menekan tindak kekerasan terhadap anak

3. Pelatihan dan praktek atau simulasi konselor sebaya untuk mengatasi tindak kekerasan pada anak

Pelatihan yang ditawarkan diharapkan dapat bermanfaat untuk meningkatkan ketrampilan Forum Anak Surakarta sebagai pendidik sebaya sebagaimana 
dapat dilihat dari bagan berikut ini (Yuliani, Humsona, Pranawa, 2018):

\section{Gambar 1. Alur Pemberdayaan Masyarakat}

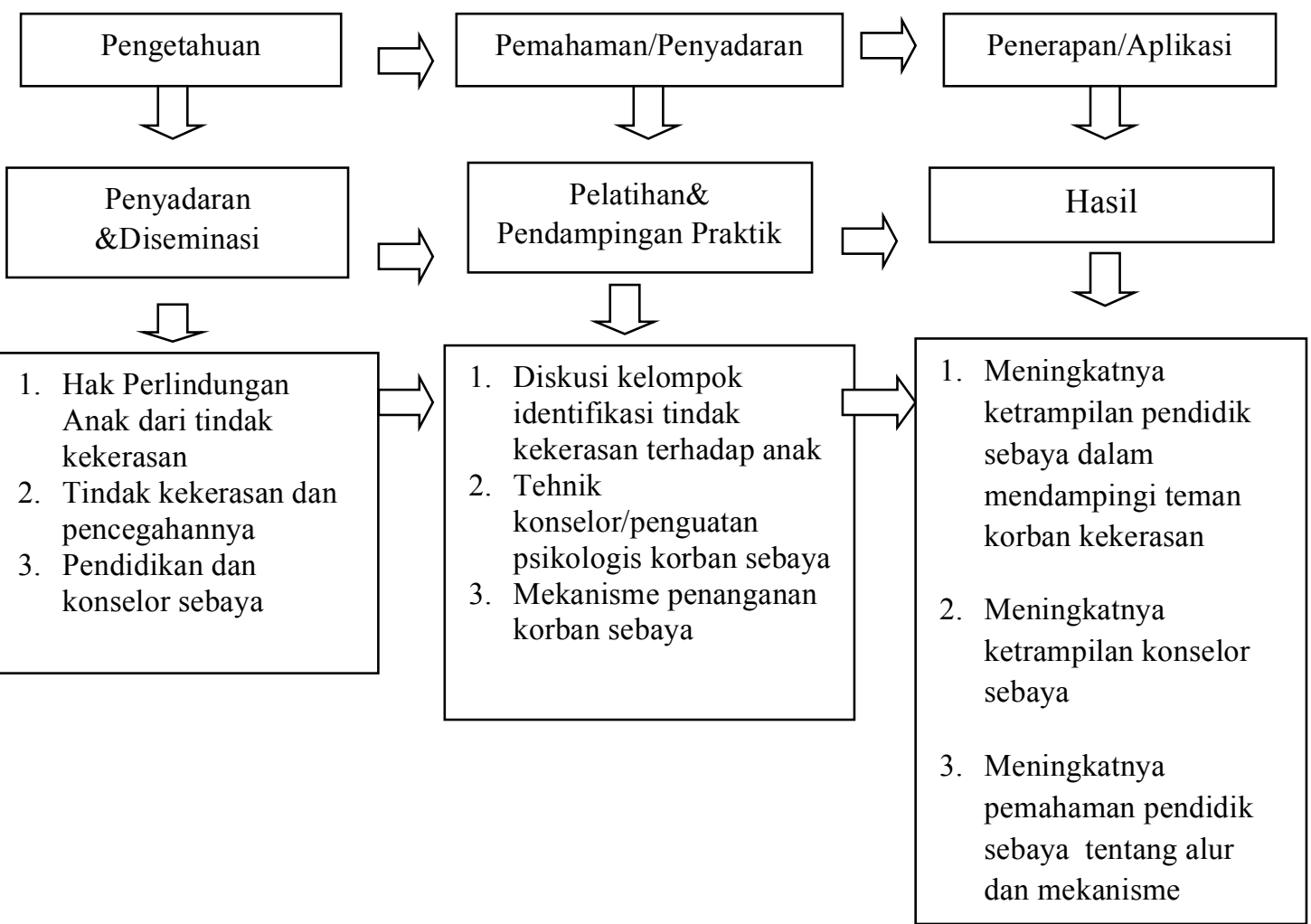

\subsection{Kegiatan Pemberdayaan Forum Anak} Surakarta sebagai Peer Educator untuk Mengatasi Tindak kekerasan terhadap Anak

Kegiatan pengabdian PKM dilakukan melalui dua tahap yaitu Kegiatan Penyadaran dan Pelatihan atau Praktek Konselor Sebaya.

\subsection{Kegiatan Penyadaran}

Kegiatan penyadaran diikuti oleh 14 anak yang tergabung dalam Forum Anak
Surakarta. Kegiatan diawali dengan paparan tentang fenomena kekerasan terhadap anak jenis, dampak dan pencegahannya. Topik ini dimaksudkan untuk membuka wawasan peserta pelatihan tentang massive-nya tindak kekerasan terhadap anak di Indonesia. Paparan lebih banyak disampaikan melalui pemutaran beberapa film pendek tentang trend kekerasan anak di Indonesia, bentuk-bentuk kekerasan, dampak kekerasan bagi anak, serta peran anak sebagai Pendidik Sebaya (Peer Educator) untuk mengatasi tindak kekerasan terhadap anak. 


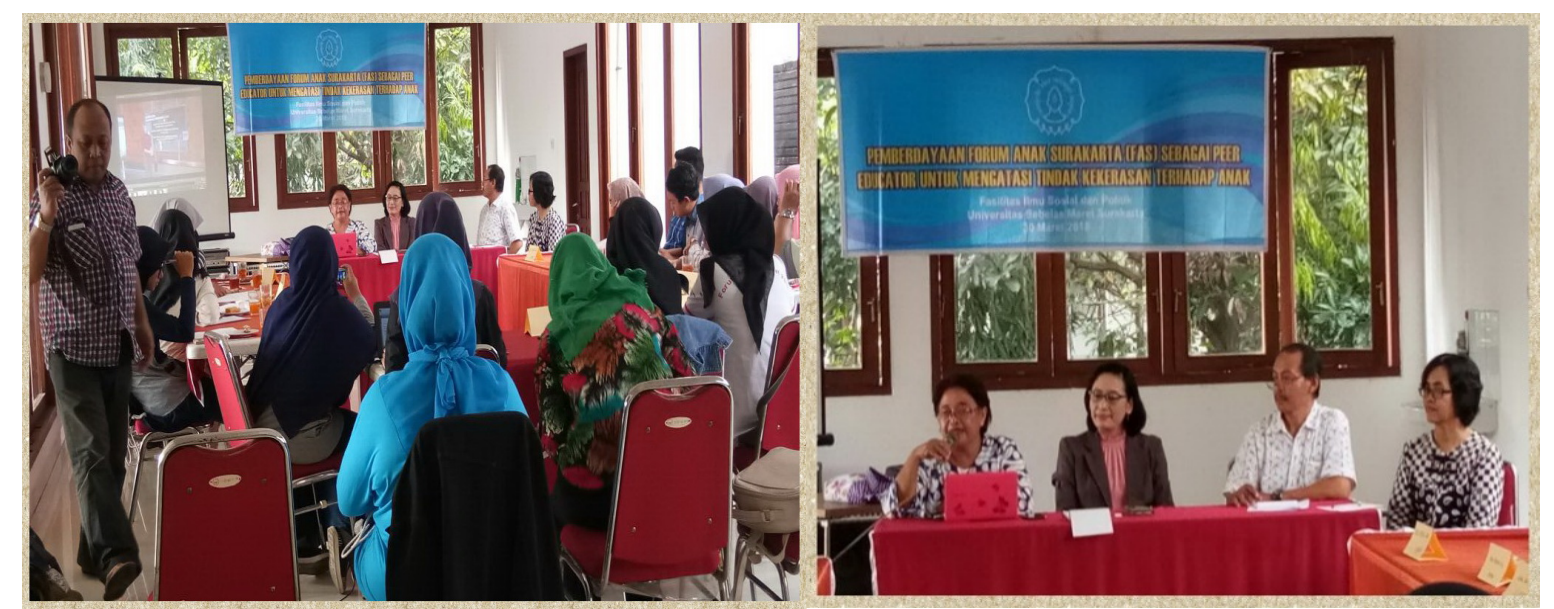

Gambar 2 : Pemutaran Film tentang Fenomena Kekerasan Terhadap Anak dan Dampaknya (sumber: dokuemen peneliti)

Kegiatan selanjutnya mendiskusikan kiat-kiat agar Forum Anak Surakarta bisa menjadi Peer Educator sekaligus Advokator bagi anak (teman) sebaya yang mengalami tindak kekerasan, khususnya melalui partisipasi FAS dalam Musyawarah

Perencanaan Pembangunan. Usai pemutaran film pendek tentang fenomena kekerasan terhadap anak dan penyampaian strategi menjadi advokator bagi anak korban kekerasan melalui partisipasi FAS dalam Musyawarah Perencanaan Pembangunan (Musrenbang). Acara dilanjutkan dengan tanya jawab dan diskusi kelompok tentang isi pesan dan informasi yang disampaikan oleh film yang telah diputar.
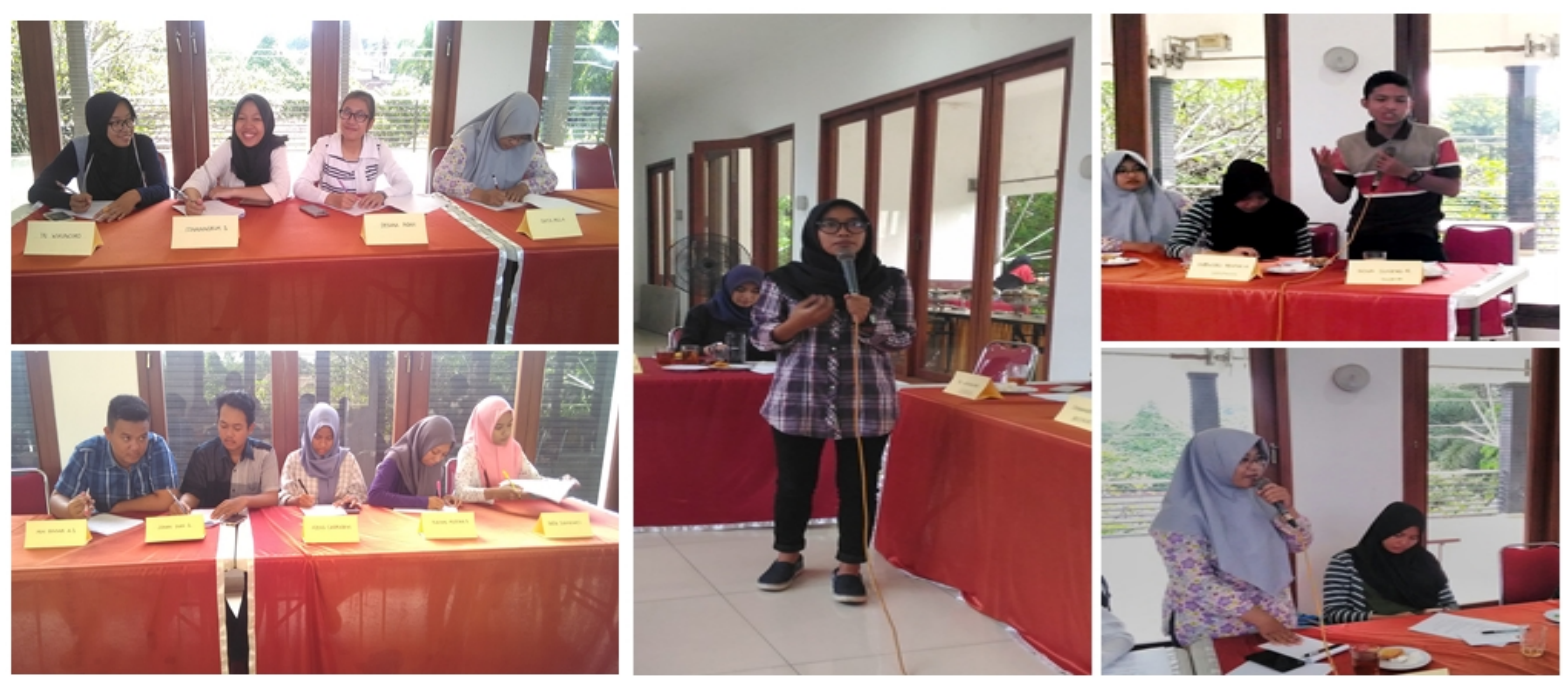

Gambar 3 : Diskusi di Sesi Penyadaran tentang Kekerasan Anak dan Dampaknya (sumber: dokumen peneliti)

Selain diskusi, kepada peserta juga diajukan beberapa pertanyaan terkait dengan isi pesan film untuk mengetahui sejauh mana pemahaman mereka terhadap bentuk-bentuk kekerasan terhadap anak dan dampaknya. Dari jawaban pertanyaan dapat diketahui bentuk 
kekerasan yang umum ditemui di lingkungan sekitar anggota FAS adalah bullying di sekolah (dijawab oleh semua atau 14 anak). Adapun bentuk bullying mulai yang ringan seperti diejek kondisi fisiknya, dipanggil bukan namanya atau dikucilkan sampai bullying fisik seperti ditendang dan dijambak. Pelaku bullying tidak hanya sesama murid tapi juga guru.

Bentuk kekerasan yang dilakukan guru adalah menendang dan memanggil murid bukan namanya dan yang paling membuat anak down adalah apabila guru menyindir anak yang membuat kesalahan secara terus menerus atau menggosipkan anak yang bermasalah. Ada 1 (satu) anak yang melaporkan kasus kekerasan fisik oleh orang tua dan 5 (lima) anak melaporkan terjadinya kekerasan seksual di lingkungan dekat mereka. Bentuk kekerasan seksual yang terjadi sudah tergolong berat seperti dicabuli teman sendiri sampai perkosaan (data diolah dari jawaban kuesioner 14 anggota FAS)

\subsubsection{Pelatihan Konselor Sebaya}

Kegiatan kedua pengabdian PKM merupakan kegiatan inti yaitu praktek atau simulasi menjadi Pendidik Sebaya bagi anak korban kekerasan. Kegiatan pelatihan diawali dengan paparan tentang "Teman dan Pendidik Sebaya" yang dimaksudkan untuk membuka wawasan peserta pelatihan tentang peran penting teman sebaya bagi anak khususnya terkait tindak kekerasan terhadap anak.

Kegiatan berikutnya diisi dengan pelatihan konselor sebaya dan simulasi pendampingan bagi teman sebaya yang mengalami tindak kekerasan. Praktek konselor sebaya dilakukan dengan metode diskusi kelompok, studi kasus, curah pendapat, dan simulasi melalui peran teater. Kasus kekerasan yang dipilih untuk disimulasikan ditentukan berdasarkan temuan kasus-kasus kekerasan dari hasil Pre-Test yaitu bullying di sekolah, kekerasan oleh orang tua dan kekerasan seksual. Peserta pelatihan dibagi ke dalam kelompokkelompok dan mereka diminta untuk memilih kasus kekerasan yang akan disimulasikan. 

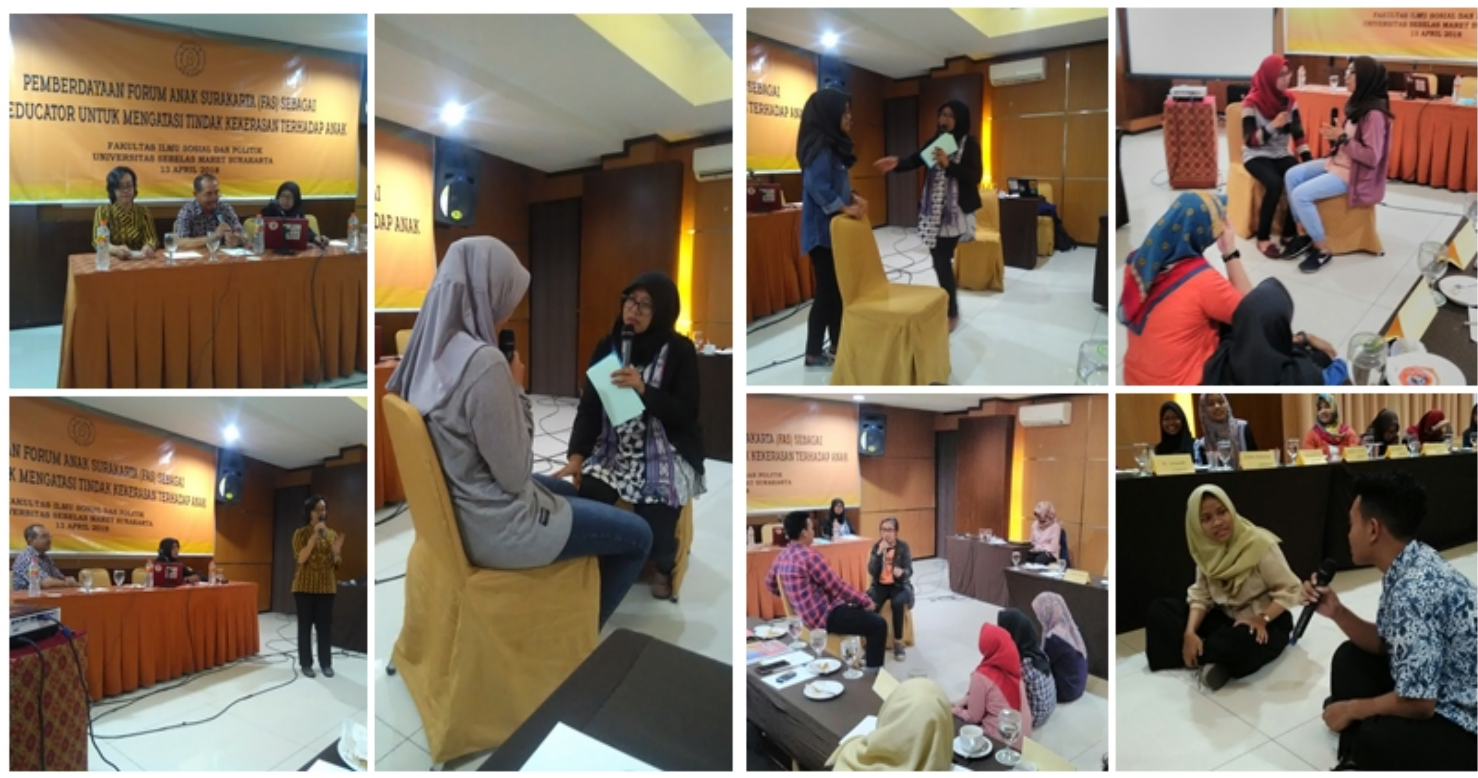

Gambar 4 : Praktek Konselor Sebaya (sumber: dokumen peneliti)

\subsubsection{Refleksi Kegiatan Pelatihan}

Tahapan pelaksanaan kegiatan pengabdian secara umum dapat dikatakan berjalan dengan lancar dan sukses dimulai dengan tahapan perencanaan atau persiapan kegiatan yang meliputi koordinasi dengan anggota tim pembantu kegiatan maupun dengan kelompok mitra; menyusun dan melaksanakan pre-test; mengevaluasi hasil pre-test; menyusun materi pelatihan; kegiatan penguatan kapasitas dan diseminasi hasil lewat website Laboratorium Program Studi Ilmu Administrasi Negara "Laboratory for Public Governance Reform" FISIP UNS di http://lpgr.fisip.uns.ac.id/?page $\mathrm{id}=1044$ dan http://lpgr.fisip.uns.ac.id/ ?page $\mathrm{id}=1064$.

Kegiatan pengabdian menghadapi sedikit kendala dalam menentukan hari dan waktu kegiatan disebabkan kelompok sasaran merupakan anak sekolah sehingga jadwal pelatihan hanya bisa dilakukan di Sabtu sore atau hari Minggu atau di hari libur. Selain itu di bulan April sampai Agustus banyak event yang melibatkan FAS seperti adanya ujian SMA dan test masuk perguruan tinggi, puasa dan lebaran. Di bulan Agustus kegiatan Forum Anak juga dipadati dengan acara menyambut perayaan Kemerdekaan Indonesia. Berdasar saran Pembina Forum Anak maka kegiatan pengabdian diputuskan diselenggarakan di hari libur dan acara berlangsung tidak sampai malam.

Kelompok sasaran memberi respon positif dan menginginkan agar kegiatan ini dilanjutkan dengan materi penguatan kapasitas yang berbeda. Kegiatan PKM ini telah berhasil menjalin kerjasama yang solid dan saling menguatkan antara Tim Dosen UNS dengan mitra (Yayasan Kakak dan FAS). Tim PKM dan Kelompok Mitra 
bersepakat untuk melanjutkan kegiatan penguatan kapasitas FAS di masa datang.

\section{PENUTUP}

Kegiatan pengabdian PKM dilakukan melalui dua kegiatan yaitu Kegiatan Persiapan PKM dan Kegiatan Pelatihan Konselor Sebaya. Sebelum dilakukan pelatihan terlebih dahulu dilakukan pre-test kepada anggota Forum Anak untuk menggali informasi sejauh mana pemahaman mereka tentang kekerasan terhadap anak dan pentingnya pendidikan sebaya. Hasil pre-test menyimpulkan materi yang penting bagi penguatan kapasitas Forum Anak Surakarta adalah: 1) Hak-Hak Anak khusunya Perlindungan Anak dari Kekerasan, 2) Pelatihan untuk menangani bullying dan kekerasan anak sejak dini, dan 3) Menjadi konselor sebaya bagi teman yang mengalami tindak kekerasan

Kegiatan pelatihan dilakukan dengan metode interaktif. Pada sesi penyadaran, anak diajak memahami fenomena kekerasan anak melalui paparan film pendek dan diberi kesempatan untuk menceritakan pengalamannya terkait dengan tindak kekerasan terhadap anak dan sejauh mana terlibat dalam pendidikan sebaya. Praktek konselor sebaya dilakukan dengan metode diskusi kelompok dan simulasi melalui diskusi kasus dan peran teater. Peserta pelatihan dibagi ke dalam kelompokkelompok dan mereka diminta untuk memilih kasus kekerasan yang akan disimulasikan. Kasus dipilih berdasarkan kasus-kasus kekerasan yang dialami anak FAS atau teman mereka sendiri yaitu bullying di sekolah, kekerasan oleh orang tua dan kekerasan seksual.

Dari hasil evaluasi dan refleksi setelah pelaksanaan pengabdian, Tim PKM UNS dan Kelompok Mitra dari LSM dan Forum Anak bersepakat untuk melanjutkan kegiatan penguatan kapasitas kepada anakanak FAS di masa datang dengan topik yang berkaitan dengan Pemenuhan Hak dan Perlindungan Anak.

\section{Daftar Pustaka}

Kementerian Pemberdayaan Perempuan dan Perlindungan Anak. (2016). Pedoman Perlindungan Anak Terpadu Berbasis Masyarakat

Isnanto, Bayu Ardi. (2016). Cegah Kekerasan Anak, Pemkot Solo Latih 'Pendidik Sebaya', Sumber : http://solo.tribunnews.com/2016/05/11/cegah-kekerasan-anak-pemkot-solo-latih-pendidiksebaya. Diakses 20 Juli 2017

Kota Solo Layak Anak Pemkot Solo Siapkan 70 Pendidik Sebaya. Sumber : http://www. koransolo.co/ 2016/03/05/kota-layak-anak-pemkot-solo-siapkan-70-pendidik-sebaya-61966. Diakses 18-2-2018 
Kuswandi. Tahun (2017), KPAI Temukan 116 Kasus Kekerasan Seksual Terhadap Anak. Sumber : https://www.jawapos.com/read/2017/09/27/159513/tahun-2017-kpai-temukan-116-kasus kekerasan-seksual-terhadap-anak. Diakses 17-2-2018

Pana, Artemis dan Lesta, Stalo. A manual for Empowering Young People in Preventing Genderbased Violence through Peer education. Penerbit The Mediterranean Institute of Gender Studies (MIGS)

Partisipasi Anak Dalam Pencegahan dan Penanganan Korban Perdagangan Anak. Sumber : https://indoact.org/2014/04/18/partisipasi-anak-dalam-pencegahan-dan-penanganan-korbanperdagangan-anak/-diakses19-2-2018

UU No.23 Th. 2002 tentang Perlindungan Anak

Warga Semakin Sadar Laporkan Kasus Kekerasan Seks pada Anak. Sumber : http://nasional.republika.co.id/berita/nasional/daerah/18/01/16/p2mmz2335-warga-semakinsadar-laporkan-kasus-kekerasan-seks-pada-anak - Diakses 17-2-2018

Yuliani, Sri., Rahesli Humsona, Rina Herlina Haryanti. (2015 dan 2016). Strategi Pengembangan Kapasitas (Capacity Building) Forum Anak Surakarta untuk Meningkatkan Partisipasi Aktif Anak Dalam Musyawarah Perencanaan Pembangunan. Laporan Penelitian Unggulan Perguruan Tinggi.

Yuliani, Sri., Rahesli Humsona, Rina Herlina Haryanti. (2017-2018). Strategi Pengembangan Kapasitas Stakeholders untuk meningkatkan Partisipasi Aktif Forum Anak Surakarta Dalam Musyawarah Perencanaan Pembangunan. Laporan Penelitian Unggulan Perguruan Tinggi.

Yuliani, Sri, Rahesli Humsona, Sigit Pranawa. (2018). Pemberdayaan Forum Anak Surakarta sebagai Peer Educator untuk Mengatasi Kekerasan Terhadap Anak. Laporan Kemajuan Program Kemitraan Masyarakat. Dana PNBP UNS 2018

Jawa Tengah Darurat Kekerasan Perempuan dan Anak. Sumber : https://nasional.tempo.co/read/ 723776/jawa-tengah-darurat-kekerasan-perempuan-dan-anak $\quad$-Diakses $\quad$ 17-2-2018 Cegah Kekerasan Anak, Pemkot Solo Latih 'Pendidik Sebaya' 